\title{
The Interest of Buying on Muslim Community to Cake and Bakery that does not Have Halal Certificate
}

\author{
Ishaq $^{1}$, Lilik Noor Yuliati ${ }^{2}$, Ahmad Sulaeman $^{3}$ \\ ${ }^{1}$ School of Business, Bogor Agricultural University (IPB), Jl. Raya Pajajaran Bogor Indonesia16151, Indonesia \\ ${ }^{2}$ Department of Family and Consumer Science, Faculty of Human Ecology, Bogor Agricultural University (IPB) \\ Jl. Raya Dramaga Bogor Indonesia 16680, Indonesia \\ ${ }^{3}$ Department of Community Nutrition, Faculty of Human Ecology, Bogor Agricultural University (IPB) \\ Jl. Raya Dramaga Bogor Indonesia 16680, Indonesia
}

\begin{abstract}
Research of interest on Muslim society in buying cake and bakery products that have not been certified halal done in the city of Bogor. 120 respondents obtained in this study are scattered from different gender, age, occupation, education level, and income. This study consists of 5 exogenous variables and 2 endogenous variables. Data were analyzed with Partial Least Square using SmartPLS 2.0 program. Variable product quality, awareness, promotion significantly influence purchase of intention. Self identity variable has significant effect to awareness. The significant effect of the variable is known by the t-count $>$ t tab (1.96). The implications of consumer protection under Law No. 8 of 1999, on government policies, business actors, and consumers.
\end{abstract}

Keywords: interest buy, purchase of intention, halal, cake dan bakery, smartPLS 2.0, Law No.8 of 1999

\section{Introduction}

The number of Indonesian Muslim population in 2010 is 207.176 .162 people or $87 \%$ of the total population of Indonesia. This number makes the population of Indonesia as the majority of the largest Muslims in the world. The population of Islam City of Bogor reached 877.498 people or about $87 \%$ of the total population of Bogor (BPS 2010). The large number of Muslims in Indonesia and in the city of Bogor in particular, is seen to increase demand for halal food products as a whole. The halal food market in Indonesia is the largest market in the world that becomes a business opportunity for Islamic and non-Islamic countries (Ahmad et al 2013). Unfortunately, the marketing of halal products in Indonesia has not been able to dominate the world market. Ministry of Industry data (2017) states that the value of Indonesia's halal product exports to Malaysia is still in the 4th position below Australia, China and New Zealand

Based on a survey conducted by internal LPPOM MUI (2009-2014) people's interest in halal products reached 70\%, the number continues to increase until the year 2012 which reached $92.2 \%$. The number of halal certifications has also increased, The number of products that already have halal certification in 201347.545 consisting of 832 companies. While in 2014 amounted to 67.369 consisting of 1436 companies (LPPOM MUI 2017).

But unfortunately, on the other hand there are still few of cake and bakery industries in Indonesia who have halal certification, even many national cake and bakery stores do not have halal certificate. Some examples of national-scale cake and bakery that have not been halal certified (until February 2017) are Holland Bakery, Bread Talk, J-Co. While examples of local cake and bakery industries in Bogor City such as Michelle and Roti Bogor Permai (until February 2017).

Top Brand Award 2014-2016 shows that cake and bakey industries that do not have halal certificate actually dominate the purchase of Indonesian people who are predominantly Muslim. The results of the survey are presented in Table 1.

Table 1: Top Brand Award 2014-2016 Survey Results

\begin{tabular}{|c|c|c|c|}
\hline \multirow{2}{*}{ Product Name } & \multicolumn{3}{|c|}{ Market Share per Year } \\
\cline { 2 - 4 } & 2014 & 2015 & 2016 \\
\hline Holland Bakery & 25.0 & 27.8 & 29.8 \\
\hline Bread Talk & 23.9 & 24.1 & 11.7 \\
\hline Majestyk & 5.9 & 5.0 & 4.3 \\
\hline Swiss Bakery & 3.6 & 2.7 & 2.5 \\
\hline Roti Boy & 3.0 & 3.6 & - \\
\hline Buana Bakery & 2.5 & - & - \\
\hline Virgin & 2.1 & - & - \\
\hline Suzzana & 2.1 & - & - \\
\hline
\end{tabular}

Source: Portal Top Brand Award (2017)

Other research conducted by Aziz and Vui (2012), concluded that the awareness of halal, halal certificate, promotion, brand positively influence the interest in buying halal products. Yunus et al (2014), concluded that halal awareness and product composition affect consumer buying interest in products produced by non-Muslims. Another study conducted by Salman and Siddiqui (2011) concluded that a person who is very religious does not necessarily have a high level of awareness of halal food. According Ardyanti (2013), Muslim consumer awareness of halal food is influenced by the understanding of the concept of halal. Masitoh (2013), stated a positive relationship between halal awareness with the perception of halal certificate.

Halal certificates are a guarantee of security for Muslims to consume a product (Aziz and Vui 2013). Nevertheless, halal

\section{Volume 6 Issue 12, December 2017}




\section{International Journal of Science and Research (IJSR) \\ ISSN (Online): 2319-7064}

Index Copernicus Value (2016): 79.57 | Impact Factor (2015): 6.391

certificates do not yet have legal legitimacy because the inclusion of halal is not an obligation laid down by law, but based on the voluntary initiatives of business actors on the presentation of their products (Hasan 2014). This condition of course also occurs in the bakery industry or known as cake and bakery. Halal certificates are not yet required for cake and bakery industries in Indonesia, still only on voluntary initiatives.

Based on the background, the purpose of this study are:

1) Analyzing the influence of product quality, awareness, promotion of purchase of intention of cake and bakery products that have not been certified halal.

2) Analyzing the influence of religious belief, self identity, halal certification to awareness of cake and bakery products that have not been certified halal.

\section{Data}

The type of data used in this study are primary and secondary data. Primary data was obtained from interview with questioner. Secondary data is obtained from previous research, literature, books and internet.

The sample in this study amounted to 120 people with the criteria of Muslim consumers who have bought cake and bakery products that have not been certified halal until February 2017.The primary data taken in April 2017.

\section{Methodology}

The research approach used is descriptive research. Descriptive is a research method that aims to describe the characteristics of an object of people, groups, organizations and environment, one of the popular approach in this research called survey approach (Sumarwan 2015).

Sampling technique used in this research is Non probability sampling that is convenience sampling method. Nonprobability Sampling is a technique that does not provide the same opportunity or opportunity for every element or member of the population to be selected as sample (Sugiyono 1999). Convenience sampling is a sampling technique in a crowded place that can be found around the campus, shopping centers, places of worship, or place of arisan.

Criteria of respondents in this study are: 1 . Consumers are Muslims, 2. Consumers who have bought cake and bakery products that have not been certified halal until February 2017 in the city of Bogor.

Data were collected through interviews for approximately 15 minutes with the help of using questionnaire instruments that have been prepared. Interviews conducted by providing a list of questions to the consumers of cake and bakery that does not have halal certification in the city of Bogor. Scale used in this research is Likert scale with score range 1-5. Likert scale is a measurement method used to measure attitudes, opinions and perceptions of a person or group of people about social phenomena (Sugiyono 1999). Data was analyzed with validity test, reliability test and partial least square structural equation modeling (PLS-SEM). PLS is an alternative method based approaches variance or component oriented model predictions with the following steps : making operational definitions, parameter estimation, evaluation of goodness of fit and hypothesis testing (Jaya and Sumaertajaya, 2008)

\section{Result}

Validity is a measure that indicates the validity levels of an instrument. A valid instrument has high validity. Conversely, a less legitimate instrument means low validity. The validity tested was using factor analysis methods and parameters such as Factor Loading. The result of this pretest consistency test is said to be valid if it has a value which is greater than 0.5 .

According to Arikunto (2010) reliability has the sense that an instrument is quite reliable to be used as a data gathering tool because the instrument is good. For testing the reliability, The test is done by usingscale analysis method performing the coding process on pretest results. Know the level of reliability as shown in the form of Cronbach's alpha value. The results of this test are based on Cronbach's alpha parameter values which is greater than 0.6.

SEM technique used in this research is PLS with SmartPLS Version 2.0 software specially designed to estimate structural equations based on variance.

The gender characteristics of respondents, men and women are almost the same, which men reach 51.7 percent and women by 48.3 percent. The most dominant age characteristics of respondents are aged 20-30 years 43.3 percent and age 31-40 years of 35.8 percent. Based on the status of respondents, 71.7 percent of respondents are married. 75 percent of respondents educational level is dominated by graduates Bachelor (S1). In the second rank 21.7 percent of respondents are post graduate (S2). While high school graduates have the least amount of 3.3 percent. The characteristics of respondents who bought cake and bakery were dominated by private employees by 41.7 percent followed by entrepreneurs 16.7 percent. The highest revenue of cake and bakery buyers who have not been certified halal is in the range of Rp. $<5$ million and $\mathrm{Rp}$. 5-10 million of which are respectively 35 percent.

\subsection{The Influence of Product Quality, Awareness, Promotion to Purchase of Intention}

Based on the results of PLS calculation in table 2, the factor of Product Quality to Purchase of Intention is significant with the value of $\mathrm{t}$-count is 2.146 . If the value of $\mathrm{t}$-count is greater than t-table then the hypothesis is accepted. The results of this study are in accordance with previous research conducted by Newberry et al (2003), where they found that product quality is the deciding factor in the purchase of intention. However, the results of this study differ from the results of research conducted by Aziz and Vui (2013), in a study conducted in Malaysia. The product quality has no significant impact on purchase of intention. Product Quality in food plays an important role in the purchase of intention, factors in the product quality are taste, appearance, ingredients in the cake and bakery. Product quality can also be associated with food safety elements in accordance with

\section{Volume 6 Issue 12, December 2017}




\section{International Journal of Science and Research (IJSR) \\ ISSN (Online): 2319-7064}

Index Copernicus Value (2016): 79.57 | Impact Factor (2015): 6.391

the content of these ingredients. According to Canavari et al (2010), food security is a basic aspect of product quality.

Law No. 18 of 2012 states that food is a basic human need, the most important and fulfillment, is part of the human rights of every people of Indonesia. Food must always be available sufficiently, safely, qualified, nutritious and diverse at a price affordable to people's purchasing power, and not contrary to the religion, beliefs and culture of society (Djamil, 2013). According to Canavari et al (2010), food security is a basic aspect of product quality.

Based on the calculation of PLS in table 2, the Awareness factor to Purchase of Intention is significant with the value of $\mathrm{t}$-count is 2.932. If the value of $\mathrm{t}$-count is greater than $\mathrm{t}$-table then the hypothesis is accepted. The results of this study in accordance with previous research conducted by Aziz and Vui (2013), in the research awareness significant impact on purchase of intention. Empirical studies conducted by Alam and Sayuti (2001) on the purchase of intention on halal food also indicate a significant relationship between awareness of purchase of intention.

Based on the calculation of PLS in table 2, Promotion factor to Purchase of Intention is significant with the value of $t$ count is 6.512 . If the value of $t$-count is greater than t-table then the hypothesis is accepted. The results of this study in accordance with previous research conducted by Aziz and Vui (2013), in the promotion of promotion significant impact on purchase of intention. The results of the study show that promotion plays an important role in persuading and motivating someone to make a purchase. The very influential promotion factor is incentive promotion on social media and print media. Another promotion factor is with the discount of cake and bakery products on certain days and certain celebration events. Discount of the given product can reach $50 \%$ from the day of cake and bakery products, it certainly will be able to attract the public to make the purchase of cake and bakery products.

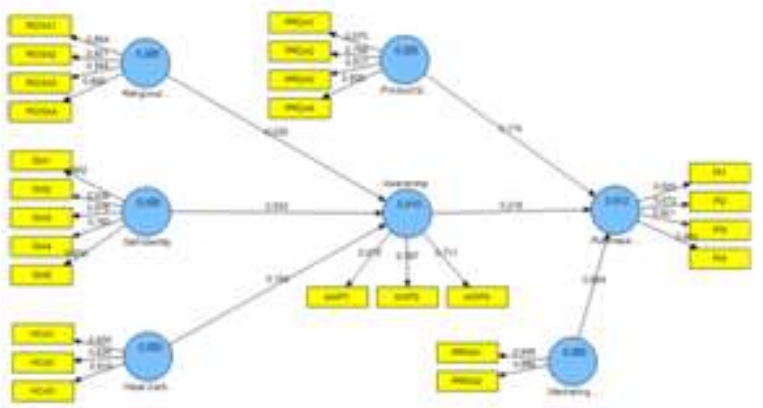

Figure 1: Structural Equation Model Loading Factor

Table 2: Results of hypothesis testing Modeling of Structural Equations with Partial Least Square

\begin{tabular}{|c|c|c|c|}
\hline $\begin{array}{c}\text { Causality relation } \\
\text { (Direct influence) }\end{array}$ & $\begin{array}{c}\text { Coef. } \\
\text { Line }\end{array}$ & $\begin{array}{c}\text { T- } \\
\text { Count }\end{array}$ & Conclution \\
\hline Product quality-> Purchase & 0.174 & 2.146 & Significant \\
\hline Awareness-> Purchase & 0.219 & 2.932 & Significant \\
\hline Promotion-> Purchase & 0.504 & 6.512 & Significant \\
\hline Religious->Awareness & -0.030 & 0.258 & Not Significant \\
\hline SelfIdentity->Awareness & 0.533 & 3.442 & Significant \\
\hline Certification-> Awareness & 0.163 & 1.659 & Not Significant \\
\hline
\end{tabular}

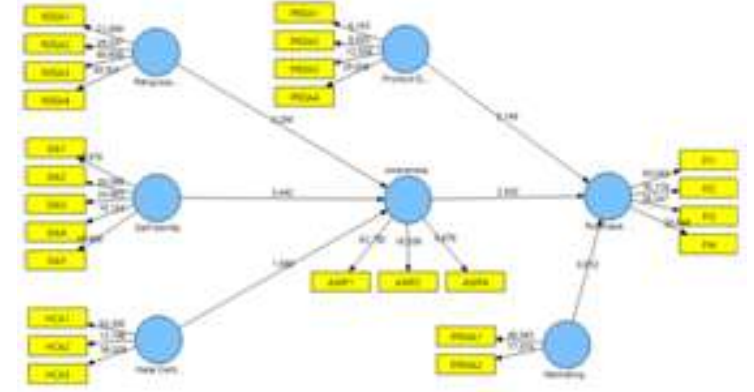

Figure 2: Model of Consumer T-Structural Equations

\subsection{The influence of Religious Belief, Self Identity, Halal Certification against Awareness}

The results of PLS calculation in table 2 shows that the Religious Belief factor to Awareness is not significant with the value of $\mathrm{t}$-count is 0.258 . If the value of $\mathrm{t}$-count is smaller than t-table then the hypothesis is rejected. The results of this study indicate that people who are very religious do not necessarily have a high awareness about halal food products, especially on cake and bakery products. There are several things that caused a person with a high religious level has no awareness of halal cake and bakery foods. One of them is the perception that in Indonesia, almost all of the food are halal. The perception is that as long as the food does not contain pork and alcohol then the food is halal. There is also lack of knowledge about the critical point of halal eating especially on the cake and bakery, where there are 15 critical points halal cake and bakery products (LPPOM MUI 2017), starting from materials such as wheat flour, tools used such as brush, and mixed ingredients such as developers, chocolate, cheese, creamer, gelatin and others.

The results of this study indicate that $65 \%$ of respondents know that rhum on cake and bakery is haram. However, as mentioned above there are 15 critical points of halal cake and bakery products, from the results of the study showed that $51.7 \%$ of respondents did not know the 15 critical points of halal cake and bakery products, and $61.7 \%$ of respondents did not know that gelatin, chocolate, cheese in some cake and bakery are not halal yet. The result of this study is also in accordance with research conducted by Salman and Siddiqui (2011) in Pakistan, where people in Pakistan do not have a high religious belief on the awareness of halal food.

The calculation of PLS in table 2 shows that the factor of Self Identity to Awareness is significant with the value of tcount is 3.442 . If the value of $t$-count is greater than t-table then the hypothesis is accepted. The result of this study indicates that the self-identity has effect on awareness.

According to Hofstede 1984, religion is regarded as a private matter and the decision to consume either kosher food or not only based on intrinsic values rather than extrinsic. Intrinsic value is a factor of within the society, while extrinsic factor comes from external influences such as family, friends and environment. In this research we can see that the environmental factors such as family have a very big influence for the formation of one's self identity in making the purchase of cake and bakery. The presence of embarrassment and pride in buying halal products is also a 


\section{International Journal of Science and Research (IJSR) \\ ISSN (Online): 2319-7064}

Index Copernicus Value (2016): 79.57 | Impact Factor (2015): 6.391

reason for the community for the formation of self-identity. The results of this study are not in accordance with research conducted by Salman and Siddiqui (2011) which states that self-identity has no significant effect on awareness.

The calculation of PLS in table 2 shows that the Halal Certification to Awareness factor is not significant with the value of $\mathrm{t}$-count is 1.659 . If the value of $\mathrm{t}$-count is smaller than t-table then the hypothesis is rejected. The results of this study indicate that halal certification has no effect on awareness. People still have not paid attention to halal certification especially on cake and bakery products.

The results of this study indicate that $69.2 \%$ of respondents do not know that the cake and bakery products they bought have not been halal certified. And $69.2 \%$ of respondents also never ask halal cake and bakery products that will be purchased at the cake and bakery shop keepers whether the cake and bakery products not have halal certificate or label halal. The results of this study are not in accordance with research Masitoh (2013), This study concluded a positive relationship between halal awareness with the perception of halal certification.

Most cake and bakery producers do not have halal certification either because halal certification is not mandatory for business actors, but it is voluntary, so halal certification does not have strong legal legitimacy, therefore does not provide protection and legal certainty of halal food products for consumers.

Consuming kosher products according to religious beliefs (Islam) for the quality of life is the right of citizens guaranteed by the 1945 Constitution, especially the Consumer Protection Law No. 8 of 1999 (Hasan, 2014). And also consume halal food is an obligation for every Muslim society (Apriyantono, 2013).

According to Pelu (2009), halal certification has several functions, for consumers: 1. Protecting Muslim consumers from consuming food-drugs and cosmetics that are not kosher, 2. Psychologic feelings of the heart and the consumer will be calm, 3. Maintain the soul and Body from the downturn caused by illicit products, 4. Provide legal certainty. For Manufacturers, Halal certification 1.As accountability to Muslim consumer, 2.Increasing trust and satisfaction of consumer, 3.Improving image and competitiveness of company, 4.As a marketing tool and expanding network area of marketing, 5.Providing benefits to producers by increasing power Competitiveness and turnover of production and sales.

\section{Conclution}

Research on the interest of Muslims society to buy cake and bakery that does not have halal certificate shows that selfidentity significantly affects the awareness of the community. As for religious belief and halal certification does not significantly affect awareness.

Product quality, awareness and promotion are variables affecting purchase of intention. Product quality, awareness and promotion significantly influences the purchase of intention.

Based on existing conclusions, of course, the researcher realized that there are limitations in various things, so that the need for improvement in all aspects of research, among others is to note the factors that influence exogenous variables such as awareness and purchase of intention. In the next study, it is expected to add some indicators and variables that may affect exogenous awareness variables such as perseption, religious commitment and attitude of halal food. For variables affecting purchase of intention can be added variable brand and loyalty.

\section{Implications on Consumer Protection}

Under the Consumer Protection Act No. 8 of 1999 , Consumer Protection is any effort that ensures legal certainty to provide protection to consumers. The law regulates consumer rights and also obligations for producers, including cake and bakery producers.

In Chapter 3 Section 4 it is explained that consumer rights are:

a) Right to comfort, security and safety in consolidating goods and / or services;

b) The right to choose goods and / or services and to obtain the goods and / or services in accordance with the exchange rate and the conditions and promised warranties;

c) The right to true, clear and honest information about the condition and guarantee of goods and / or services;

d) The right to be heard of his opinions and complaints on the goods and / or services used;

e) The right to adequate advocacy, protection and dispute resolution of consumer protection;

f) Right to counseling and education of consumers;

g) The right to be treated or served properly and honestly and not discriminatively;

h) The right to compensation, indemnification and / or reimbursement, if the goods and / or services received are not in accordance with the agreement or not as they should be;

i) Rights set forth in the provisions of other laws and regulations.

While the obligations of entrepreneurs described in Chapter

3 section 7 are:

a) Having good faith in doing business;

b) Provide true, clear and honest information about the condition and guarantee of goods and / or services and provide explanations of the use, repair and maintenance;

c) Treat or serve consumers properly and honestly and nondiscriminatively;

d) Guarantee the quality of goods and / or services produced and / or traded under the provisions of the applicable quality standards of goods and / or services;

e) Provide an opportunity for consumers to test, and / or to try certain goods and / or services and provide guarantees and / or warranties on manufactured and / or traded goods;

f) Compensate, indemnify and / or reimburse for losses arising from the use, use and utilization of traded goods and / or services; 


\section{International Journal of Science and Research (IJSR) \\ ISSN (Online): 2319-7064}

Index Copernicus Value (2016): 79.57 | Impact Factor (2015): 6.391

g) Compensate, indemnify and / or reimburse if the goods and / or services received or utilized are not in accordance with the agreement.

According to Section 4 points a and $\mathrm{c}$ it is explained that the right to comfort, safety and safety in consuming goods in this case cake and bakery, as a Muslim is certainly one aspect of comfort, safety and safety is the existence of halal certificate. While the information is true, clear and honest also must be informed by cake and bakery entrepreneurs, so that the Muslim community to know clearly information about the product including halal cake and bakery products.

Whereas according to Section 7 point $b$ it is explained that the entrepreneur must provide correct, clear and honest information about the condition and guarantee of goods and / or services and give explanation of the use, repair and maintenance, including in providing information about halalness of cake and bakery products.

The results showed that there are several things that can be done by the government, business actors and consumers, including:

1) The government must immediately obligate halal certification for all business actors, especially those engaged in food, beverages and cosmetics, it will make halal certification has a strong and definite legal legitimacy, so that consumers get a clear protection and certainty of food law.

2) Business actors provide correct and honest information about the condition of cake and bakery it produces. And participate in the manufacture of halal certification for the protection and certainty of consumer law.

3) Muslim consumers to selectively choose and pay more attention to halal certification of cake and bakery products that will be bought, always pay attention to the existing halal label and even directly ask to the seller about halal cake and bakery products that are still dubious halal.

\section{References}

[1] Ahmad NA, Abaidah TN, Yahya MHA. 2013. A Study on Halal Food Awareness Among Muslim Customers in Klang Valley. The 4th International Conference in Business and Research (4th icber 2013) Proceeding, 1073-1087

[2] Alam, S. S., \&Sayuti, N. M. (2011). Applying the Theory of Planned Behavior(TPB) in Halal Food Purchacing. International Journal of Commerce and management, 21(1),8-20.

[3] Apriyantono A. 2013. LPPOM MUI HarusDiperkuat.Jurnal Halal. No.99 Th. XVI : 48

[4] Ardyanti N et al. 2013. A Study on Halal Awareness Among muslim Customers in Klang Valley. 4th International Conference on Business Economic Research Proceeding

[5] Arikunto S. 2010. Prosedur Penelitian Suatu PendekatanPraktek. Jakarta (ID): PT RinekaCipta.

[6] Aziz YA,Vui CN. 2012. The Role of Halal Awareness, Halal certification and Marketing Components in Determining Halal Purchase Intention Among NonMuslims in Malaysia: A Structural Equation Modeling
Aproach. Jounal of International Food \& Agribusiness Marketing, 25(1): 1-23.

[7] [BPS] BadanPusatStatistik. 2010. SensusPenduduk 2010. Jakarta [ID]: BPS.

[8] Canavari, M., Castellini, A., \&Spadoni, R. (2010). Challenges in marketing quality food products.Journal of International Food \& Agribusiness Marketing, 22(34), 203-209.

[9] Djamil, F. 2013. KalauBanyakLembaga Fatwa, UmatBisaBingung .Jurnal Halal. No.100 Th.XVI, LPPOM MUI :48-49

[10] Hasan SKN. 2014. Kepastian Hukum Sertifikasidan Labelisasi Halal ProdukPangan.Disertasi. Palembang [ID]: Program Studi Doktor Ilmu Hukum Fakultas Hukum UniversitasSriwijaya.

[11]Hofstede, G., (1984). The Cultural Relativity of the Quality of Life Concept. The Academy of Management Review. Vol.9, Iss: 3, pp. 389-398

[12] Jaya IGNM., danSumertajaya IM., 2008. Pemodelanpersamaan structural dengan partial least square.Prosiding Seminar Nasional Matematikadan Pendidikan Matematika:1(8).

[13][Kemenperin] KementerianPerindustrianRepublik Indonesia. 2017. Produk Halal RI BelumMendominasi. [internet]. [2017 Februari 14]. Tersedia dari: http://www.kemenperin.go.id/artikel/1830/ProdukHalal-RI-\%20Belum-Mendominasi

[14][LPPOM

MUI]

LembagaPengkajianPanganObatobatandanKosmetikaMa jelisUlama Indonesia. 2017. Tentang LPPOM MUI. [internet]. [diacu pada 2017 Februari 14]. Tersedia dari: http://www.halalmui.org/muil4/index.php/main/go_to_s ection/2/31/page

[15] LPPOM

MUI]

LembagaPengkajianPanganObatobatandanKosmetikaMa jelisUlama Indonesia. 2017. Titik Kritis Kehalalan Bakery. [internet]. [diacu pada 2017 Februari 14]. Tersedia

dari:http://www.halalmui.org/mui14/index.php/main/det il_page/48/2141

[16] Masitoh SA, Rafida NAR, Alina AR. 2013. Perception Towards Halal Awareness and its Corellation with Halal Certification among Muslim. Middle East Journal of Scientific Research 13(Approaches of Halal and Thoyyib for Society, Wellness and Health). 01-0

[17] Newberry, R. C., Klemz, B. R., \&Boshoff, C. (2003). Managerial Implications of Predicting Purchase Behavior from Purchase Intentions : A Retail Patronage Case Study. Journal of Services Marketing. 17(6), 609. 620

[18] Pelu, $\quad$ M. 2009. Label Halal; AntaraSpiritualitasBisnisdanKomoditas Agama. Malang: Madani

[19]Pemerintah Republik Indonesia. 2012. UndangUndangNomor 18 Tahun 2012 tentangPangan. Jakarta [ID]: Sekretaris Negara.

[20]Portal Top Brand Award. 2017. Survey Result. [internet]. [diacu pada 2017 Februari 14]. Tersedia dari: http://www.topbrand-award.com/top-brandsurvey/survey-result

[21] Salman, F., \&Siddiqui, K,. (2011). An Exploratory Study for Measuring Consumers awareness and Perceptions Towards Halal Food in 


\section{International Journal of Science and Research (IJSR) \\ ISSN (Online): 2319-7064}

Index Copernicus Value (2016): 79.57 | Impact Factor (2015): 6.391

Pakistan,.International Jurnal of Contemporary Research in Bussiness. Vol. 3 N0.2

[22] Sugiyono. 1999. StatistikaUntukPenelitian. CV Alvabeta
[23] Sumarwan,
$\mathrm{U}$.
2004.

PerilakuKonsumenTeoridanPenerapandalamPemasaran, Ghalia Indonesia, Bogor

[24] Yunus M, Rashid W, Ariffin M,Rasyid M. 2014. Muslim`s Purchase Intention Towards Non Muslim`s Halal Packaged Food Manufacturer. Procedia-Social and Behavioral Science.145-154.

\section{Author Profile}

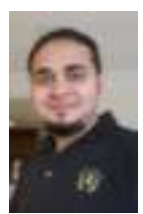

Ishaq recived Business School of Bogor Agricultural Intitute (IPB) studies in 2014. Choose deepening in marketing and consumer behavior. Interested to examine the buying interest of Muslim society against cake and bakery. Become an entrepreneur in the field of Batik business since 2013, in the city of Bandung and Bogor.

Volume 6 Issue 12, December 2017

www.ijsr.net 